\title{
PENGARUH HASIL BELAJAR EKONOMI, LINGKUNGAN KELUARGA DAN TEMAN SEBAYA TERHADAP EFISIENSI DALAM BERKONSUMSI PADA SISWA KELAS X IPS SMA NEGERI 1 TUMPANG TAHUN AJARAN 2015/2016
}

\author{
Rio Prasiska ${ }^{1}$, Hari Wahyono ${ }^{2}$, Yohanes Hadi $\mathrm{S}^{\mathbf{3}}$ \\ 1. Economic Education Program, Faculty of Economics, State University Malang \\ 2. Economic Education Program, Faculty of Economics, State University Malang \\ 3. Economic Education Program, Faculty of Economics, State University Malang \\ riyoprasiska@gmail.com, hari.wahyono.fe@um.ac.id, yohanes.hadi.fe@um.ac.id
}

\begin{abstract}
This research was conducted with the aim to describe the influence of economic study result, family environment and colleague on efficiency to consume student class X Social Science Senior High School 1 Tumpang during 2015/2016 learning period. The research metodology used is quantitative descriptive with exsplanation format. The instrument used in this research was tests and questionnaires. The number of respondents are 95 students. The data were analyzed using SPSS 21 For Windows.Based on the analysis of data obtained the following results : (1) there is influence between economic study result (X1) with efficiency to consume (Y) about 2,76\%. (2) there is influence between family environment (X2) with efficiency to consume (Y) about 26,6643\%. (3) there is influence between colleague (X3) with efficiency to consume (Y) about 7,8987\%.
\end{abstract}

Keywords: economic study result, family environment, colleague and efficiency to consume.

History of Article:

Received:(12 Januari 2017), Accepted : (19 Februari 2017), Publised : (15 Maret 2017)

\section{Citation:}

Prasiska,Rio \& Hari Wahyono \& Hadi,Yohanes (2018) Pengaruh Hasil Belajar Ekonomi, Lingkungan Keluarga Dan Teman Sebaya Terhadap Efisiensi Dalam Berkonsumsi Pada Siswa Kelas X IPS SMA Negeri 1 Tumpang Tahun Ajaran 2015/2016 [The Influence Of The Learning Outcomes Of Economic, Enviromental, Familh And Peers On The Efficiency In Consumption On The Students Of Class X IPS SMA Negeri 1 Tumpang Academic Year 2015/2016]. Jurnal Pendidikan Ekonomi, 10(1), 73-88

C) Universitas Negeri Malang 


\section{PENDAHULUAN}

Era globalisasi seperti saat ini mengakibatkan terjadinya pergeseran pola konsumsi sebagian besar masyarakat indonesia. Pengaruh globalisasi sangat terlihat di kota-kota besar. Dampak globalisasi semakin terasa setelah muncul pusat-pusat perbelanjaan dan berbagai macam barang dan jasa yang tersedia. Untuk mendapatkan sebuah barang atau jasa yang di inginkan saat ini sangat mudah dengan beragam fasilitas yang ada. Kondisi seperti inilah yang dikhawatirkan dapat mempengaruhi pola konsumsi masyarakat ke arah yang negatif. Terlebih lagi bagi seorang siswa sekolah menengah atas yang belum mempunyai pemahaman ekonomi yang baik.

Wahyono (2001) mengungkapkan bahwa manusia adalah makhluk yang rasional karena memiliki kemampuan berpikir, sehingga mampu merencanakan tindakan untuk masa mendatang, berdasarkan pemahaman atas masa lalunya dan kondisi yang dihadapi pada saat ini. Sehingga dengan demikian, peran pembelajaran ekonomi di sekolah merupakan suatu hal yang sangat penting bagi seorang siswa. Karena dengan memiliki pemahaman ekonomi yang baik, seorang siswa dapat menggunakan sumber daya yang dimilikinya untuk memenuhi kebutuhannya secara efektif dan mendapatkan kepuasan secara maksimal.

\section{Hasil Belajar Ekonomi}

Untuk mengukur baik tidaknya pemahaman ekonomi siswa dapat diketahui melalui hasil belajar ekonominya. Hasil belajar ekonomi merupakan hasil dari serangkaian proses pembelajaran ekonomi yang diterima siswa di sekolah. Slameto (2010: p.54) mengatakan bahwa "hasil belajar adalah perubahan yang terjadi secara sadar dan bersifat kontinyu dan fungsional setelah mengalami pelatihan dan pengalaman dalam kegiatan pembelajaran". Hakikat dari pembelajaran ekonomi adalah mengajarkan siswa agar bersikap bijak dalam menggunakan sumber daya yang terbatas dalam memenuhi kebutuhannya dan untuk memperoleh kepuasan yang maksimal. Dari hasil belajar ekonomi siswa yang baik tersebutlah diharapkan siswa dapat memahami pola konsumsi yang baik dan dapat terhindar dari pola konsumsi yang irasional dan berlebihan (konsumtif).

\section{Lingkungan Keluarga}

Perilaku efisiensi berkonsumsi ini selain dapat dipelajari oleh seorang siswa di sekolah juga dapat diperoleh oleh siswa melalui lingkungan keluarganya. Menurut Tirtarahardja (2005:p.168) "keluarga merupakan pengelompokan primer yang terdiri dari sejumlah kecil orang karena hubungan semenda dan sedarah". Pendidikan dalam keluarga merupakan landasan dari pendidikan anak selanjutnya. Ihsan (2011: p.57) menjelaskan bahwa "keluarga adalah merupakan lembaga pendidikan yang pertama dan utama dalam masyarakat, karena dalam keluargalah manusia dilahirkan, berkembang menjadi dewasa. Bentuk dan isi serta cara-cara pendidikan di dalam keluarga akan selalu mempengaruhi tumbuh dan berkembangnya watak, budi pekerti dan kepribadian tiap-tiap manusia".

\section{Teman Sebaya}

Faktor lain yang dapat mempengaruhi perilaku ekonomi anak adalah teman sebayanya. Teman sebaya merupakan sekumpulan anak dengan tingkat kedewasaan yang relatif sama dan secara spontan mempunyai tujuan yang sama pula. Suryani (2008: p.175) menyatakan bahwa "teman sebaya punya peran yang cukup besar 
terutama bagi anak-anak remaja dalam pembentukan sikap. Adanya kecenderungan untuk mendapatkan penerimaan dari teman-teman sebayanya mendorong para anak mudah dipengaruhi oleh kelompoknya dibandingkan oleh sumber-sumber lainnya".

Apabila sebagian besar teman sebayanya mempunyai pola konsumsi yang tidak rasional, bukan tidak mungkin seorang anak juga akan tertular perilaku tersebut. Tetapi apabila teman sebayanya mempunyai pemahaman ekonomi yang baik dan memiliki pola konsumsi yang rasional, maka anak tersebut kemungkinan juga akan terhindar dari pola konsumsi irasional dan tidak efisien.

\section{Perilaku Konsumen}

Dalam Mangkunegara (1988: p.4) "perilaku konsumen merupakan suatu tindakan-tindakan yang dilakukan oleh individu, kelompok atau organisasi yang berhubungan dengan proses pengambilan keputusan dalam mendapatkan, dan menggunakan barang-barang atau jasa ekonomi yang dapat dipengaruhi oleh lingkungan".

Menurut Handoko (2011:p.7) "efisiensi adalah kemampuan untuk menyelesaikan suatu pekerjaan dengan benar". Efisiensi berarti sebuah sikap atau perilaku menggunakan sesuatu secara efektif atau tepat guna. Dalam Kamus Besar Bahasa Indonesia (diakses secara online) efisiensi berarti ketepatan cara (usaha, kerja) dalam menjalankan sesuatu (dengan tidak membuang waktu, tenaga, biaya); kedayagunaan; ketepatgunaan; kesangkilan.

Sedangkan menurut Rosyidi (2004: p.147) bahwa "dalam ilmu ekonomi, konsumsi berarti penggunaan barang dan jasa untuk memuaskan kebutuhan manusiawi (the use of goods and services in the satisfaction of human wants)". Dalam kehidupan sehari-hari istilah konsumsi dapat diartikan sebagai tindakan makan dan minum, atau diartikan sebagai tindakan untuk menghabiskan nilai guna suatu barang atau jasa untuk memenuhi kebutuhan.

Jadi, berdasarkan pendapat ahli diatas mengenai efisiensi dan konsumsi, peneliti dapat menyimpulkan bahwa yang dimaksud dengan efisiensi dalam berkonsumsi adalah sebuah perilaku atau tindakan menggunakan/menghabiskan nilai guna suatu barang dengan menggunakan sumber daya yang dimiliki secara tepat dan efisien sehingga dapat memperoleh kepuasan yang maksimal.

\section{METODE PENELITIAN}

Penelitian ini menggunakan pendekatan penelitian kuantitatif dengan format eksplanasi. Populasi dalam penelitian ini adalah siswa kelas X IPS 3, 4 dan 5 SMA Negeri 1 Tumpang tahun ajaran 2015/2016 yang berjumlah 95 siswa.

\begin{tabular}{lll}
\hline No & Kelas & Jumlah Siswa \\
\hline 1 & X IPS 3 & 36 \\
\hline 2 & X IPS 4 & 39 \\
\hline $\mathbf{3}$ & X IPS 5 & 20 \\
\hline Jumlah & 95
\end{tabular}

Instrumen yang digunakan dalam penelitian ini berupa tes (untuk mengukur hasil belajar ekonomi) dan angket (untuk mengukur lingkungan keluarga, teman sebaya dan efisiensi dalam berkonsumsi). 
Teknik tes digunakan untuk mengukur pemahaman siswa tentang pengetahuan dasar ekonomi dengan menggunakan metode pilihan ganda dan disertai dengan 5 alternatif jawaban. Terdapat 40 soal pengetahuan dasar ekonomi dalam instrumen ini, jika benar maka akan mendapatkan skor 2,5 dan jika salah akan mendapatkan skor 0. Berdasarkan standart ditetapkan 4 kelas hasil belajar ekonomi siswa yaitu sangat baik, baik, cukup, dan buruk.

Sedangkan angket dalam penelitian ini digunakan untuk mengukur lingkungan keluarga, teman sebaya dan efisiensi dalam berkonsumsi. Terdapat 4 alternatif jawaban pada angket ini, yaitu:

Selalu/sangat baik = nilai 4

Sering/baik = nilai 3

Jarang/cukup = nilai 2

Tidak pernah/buruk = nilai 1

Dalam teknik pengumpulan data yang digunakan dalam penelitian ini sangat diperlukan adanya pengujian validitas instrumen. Pengujian tersebut dilakukan dengan tujuan untuk mengetahui kevalidan atau keabsahan suatu instrumen yang akan digunakan dalam penelitian (Sugiyono, 2007).

Jika instrumen telah dinyatakan valid, berikutnya instrumen tersebut diuji reliabilitasnya atau tingkat kebenarannya. Uji reliabilitas dalam penelitian ini dilakukan dengan program SPSS For Window Versi 21.

\section{Analisis Data}

\section{Analisis Statistik Deskriptif}

Pada analisis deskriptif ini menggunakan teknik analisis presentase dengan mencari panjang kelas interval terlebih dahulu dengan rumus: skor tertinggi-skor terendah dibagi jumlah kriteria. Kemudian total nilai tiap item dimasukan kedalam kelas interval sehingga didapat frekuensi tiap kategori dan di persentasekan dengan rumus: Frekuensi di kali 100 dibagi total jumlah responden.

\section{Analisis Regresi Linier Berganda}

Untuk mengetahui pengaruh secara parsial maupun secara simultan antara variabel bebas $(\mathrm{X})$ dengan variabel terikat( $(\mathrm{Y})$, maka digunakan analisis regresi berganda. Analisis data dalam penelitian ini menggunakan SPSS 21 For Windows. Rumus yang digunakan adalah sebagai berikut:

$\mathrm{Y}=\mathrm{a}+\mathrm{b}_{1} \mathrm{X}_{1}+\mathrm{b}_{2} \mathrm{X}_{2}+\mathrm{b}_{3} \mathrm{X}_{3} \mathrm{e}$

Keterangan:

Y = Efisiensi berkonsumsi

a $\quad=$ Konstanta

$\mathrm{b}_{1}, \mathrm{~b}_{2}, \mathrm{~b}_{3}=$ Koefisien regresi atau prediktor

$\mathrm{X}_{1} \quad=$ Hasil belajar ekonomi

$\mathrm{X}_{2} \quad=$ Lingkungan Keluarga

$\mathrm{X}_{3} \quad=$ Teman Sebaya

e $=$ error 


\section{Uji Asumsi Klasik}

\section{Uji Normalitas}

Tujuan dari pengujian ini adalah untuk mengetahui apakah residual yang diteliti terdistribusi normal atau tidak. Data dapat dikatakan normal atau tidak dapat dilihat dari One Sample Kolmogorov Smirnov, selain itu nilai residual yang terdistribusi normal adalah sebuah kurva yang berbentuk lonceng yang kedua sisinya melebar tak terhingga. Cara lain untuk mendeteksi normalitas adalah dengan melihat penyebaran data pada sumbu diagonal grafik $P-P$ Plot.

\section{Uji Multikolinieritas}

Uji multikolineritas ini dilakukan untuk menguji apakah pada model regresi ditemukan adanya korelasi antar variabel independent. Jika terjadi korelasi, maka dinamakan terdapat problem multikoliniritas atau multikol. Untuk mendeteksi adanya multikol adalah dengan cara mengetahui :

- Besaran VIF (Variance Inflation Factor) dan Tolerance Pedoman suatu model regresi yang bebas multikol adalah mempunyai nilai VIF disekitar angka 1, dan angka tolerance mendekati 1 .

- Besaran Korelasi Antar Variabel Independen Koefisien korelasi antar variabel independen haruslah lemah yaitu dibawah 0,5. Jika korelasinya kuat, maka terjadi problem multikol dalam model regresi tersebut.

\section{Uji Heterokesdatisitas}

Uji ini dilakukan untuk menguji apakah dalam sebuah model regresi terjadi ketidaksamaan varians dari residual suatu pengamatan ke pengamatan lain, jika tetap maka disebut homokedastisitas, dan jika varians berbeda disebut dengan heterokestisitas.

Deteksi ada atau tidaknya heterokedastisitas adalah dengan melihat ada atau tidaknya pola tertentu pada grafik Scatter Plot yang akan ditampilkan setelah input data.

\section{Uji Hipotesis}

\section{Uji t}

Uji t digunakan untuk menguji hipotesis tentang variabel bebas yang terpisah terhadap variabel terikat. Uji t dapat dicari dengan menggunakan rumus sebagai berikut:

$$
\mathrm{t}=\frac{r \sqrt{n}-2}{\sqrt{\mathrm{I}}-r 2}
$$

Keterangan

$\mathrm{t}=\mathrm{t}_{\text {hitung }}$ yang selanjutnya dikonsultasikan dengan $\mathrm{t}_{\text {tabel }}$

$\mathrm{r}=$ Korelasi parsial yang ditemukan

$\mathrm{n}=$ Jumlah sampel

Ketentuan tidak ditolak atau penolakan hipotesis adalah sebagai berikut:

1) Jika $t_{\text {hitung }}>$ ttabel atau nilai signifikansi $t<0,05$ maka hipotesis nol ditolak dan hipotesis alternatif tidak ditolak. 
2) Jika $t_{\text {hitung }}<t_{\text {tabel }}$ atau nilai signifikansi $t>0,05$ maka hipotesis nol tidak ditolak dan hipotesis alternatif ditolak.

\section{Uji f}

Uji $\mathrm{F}$ digunakan untuk menguji hipotesis tentang semua variabel bebas (X1,X2 dan X3) secara bersama-sama terhadap variabel terikat (Y). Adapun rumusnya adalah sebagai berikut:

Keterangan

$$
\mathrm{F}=\frac{R^{2} / k}{\left(1-R^{2}\right) /(n-k-1)}
$$

$\mathrm{F}=\mathrm{F}_{\text {hitung }}$ yang selanjutnya dibandingkan dengan $\mathrm{F}_{\text {tabel }}$

$\mathrm{R}^{2}=$ Koefisien determinasi

$\mathrm{n}=$ Jumlah sampel

$\mathrm{k}=$ Jumlah variabel bebas

Dari hasil uji F yang dilakukan tersebut dapat ditarik kesimpulan apakah hipotesis tidak ditolak atau ditolak.

1) Jika $F_{\text {hitung }}<F_{\text {tabel }}$ atau nilai signifikansi $F>0,05$ maka Ho tidak ditolak dan Ha ditolak yang berarti tidak terdapat pengaruh yang signifikan antara variabel $\mathrm{X}$ secara bersama-sama terhadap variabel Y.

2) Jika $F_{\text {hitung }}>F_{\text {tabel }}$ atau nilai signifikan $F<0,05$ maka Ho ditolak dan Ha tidak ditolak yang berarti terdapat pengaruh yang signifikan antaya variabel $\mathrm{X}$ secara bersama-sama terhadap Variabel Y.

\section{Sumbangan Efektif Variabel}

Sumbangan efektif variabel berfungsi untuk mengetahui tingkat pengaruh dari masing-masing variabel bebas terhadap variabel terikat.

\section{Koefisien Determinasi $\left(\mathbf{R}^{2}\right)$}

Besarnya koefisien determinasi dari nol sampai dengan satu. Semakin mendekati nol besarnya koefisien determinasi suatu persamaan regresi, maka semakin kecil pula pengaruh variabel bebas terhadap variabel terikat. Begitu pula sebaliknya.

Besaran pengaruh semua variabel yang ditunjukkan oleh koefisien determinasi $\left(\mathrm{R}^{2}\right)$ diperoleh dengan menggunakan bantuan komputer SPSS 21 For Windows.

\section{HASIL DAN PEMBAHASAN \\ Hasil Belajar Ekonomi}

Data hasil belajar ekonomi siswa yang diukur dengan soal tes dapat dijabarkan kedalam tabel berikut:

\begin{tabular}{lllll}
\hline $\mathrm{N}$ & $\begin{array}{l}\text { Kelas } \\
\text { o }\end{array}$ & $\begin{array}{l}\text { Kriter } \\
\text { ia }\end{array}$ & $\begin{array}{l}\text { Frekue } \\
\text { nsi }\end{array}$ & $\begin{array}{l}\text { Prosen } \\
\text { tase }\end{array}$ \\
\hline 1 & $85-100$ & $\mathrm{~A}$ & 13 & $14 \%$ \\
\hline 2 & $70-84$ & $\mathrm{~B}$ & 57 & $60 \%$ \\
\hline 3 & $60-69$ & $\mathrm{C}$ & 15 & $16 \%$ \\
\hline 4 & $<60$ & $\mathrm{D}$ & 10 & $10 \%$ \\
\hline & Jumlah & & 95 & $100 \%$ \\
\hline
\end{tabular}


Berdasarkan tabel diatas yang diperoleh dari data hasil penelitian terhadap 95 siswa dapat diketahui bahwa sebanyak 13 siswa mendapatkan nilai dengan kriteria A, 57 siswa mendapatkan nilai dengan kriteria B, 15 siswa mendapatkan nilai dengan kriteria $\mathrm{C}$ dan 10 siswa mendapatkan nilai dengan kriteria D.

\section{Lingkungan Keluarga}

Panjang kelas interval diukur dari nilai skor tertinggi dikurangi nilai skor terendah kemudian dibagi banyaknya kelas interval. Banyaknya kelas interval ditentukan rentang skor, yaitu 4 sehingga ditentukan panjang kelas interval (80-20):4 $=15$.

Data lingkungan keluarga siswa yang diukur dengan angket/kuesioner dapat dijabarkan kedalam tabel berikut:

\begin{tabular}{lllll}
\hline No & $\begin{array}{c}\text { Kelas } \\
\text { Interval }\end{array}$ & \multicolumn{1}{c}{ Kriteria } & Frekuensi & $\begin{array}{l}\text { Prosent } \\
\text { ase (\%) }\end{array}$ \\
\hline 1 & $65-80$ & Selalu/ Sangat Baik & 52 & $54,7 \%$ \\
\hline 2 & $50-64$ & Sering/ Baik & 43 & $45,3 \%$ \\
\hline 3 & $35-49$ & Jarang/ Cukup & - & $0 \%$ \\
\hline 4 & $20-34$ & Tidak Pernah/ Buruk & - & $0 \%$ \\
\hline & Total & & 95 & $100 \%$ \\
\hline
\end{tabular}

Berdasarkan tabel diatas dapat diketahui dari 95 siswa yang diteliti, sebanyak 52 siswa (54,7\%) dinyatakan memiliki Lingkungan Keluarga yang sangat baik, 43 siswa $(45,3 \%)$ dinyatakan memiliki Lingkungan Keluarga yang baik dan tidak terdapat siswa yang memiliki Lingkungan Keluarga yang cukup ataupun buruk.

\section{Teman Sebaya}

Panjang kelas interval diukur dari nilai skor tertinggi dikurangi nilai skor terendah kemudian dibagi banyaknya kelas interval. Banyaknya kelas interval ditentukan rentang skor, yaitu 4 sehingga ditentukan panjang kelas interval (68-17):4 $=12,7$ dibulatkan menjadi 13 .

Data teman sebaya siswa yang diukur dengan angkket/kuesioner dapat dijabarkan kedalam tabel berikut:

\begin{tabular}{|c|c|c|c|c|}
\hline No & Kelas Interval & Kriteria & Frekuensi & Prosentase $(\%)$ \\
\hline 1 & $56-68$ & $\begin{array}{l}\text { Selalu/ Sangat } \\
\text { Baik }\end{array}$ & 4 & $4,2 \%$ \\
\hline 2 & $43-55$ & Sering/ Baik & 45 & $47,4 \%$ \\
\hline 3 & $30-42$ & Jarang/ Cukup & 46 & $48,4 \%$ \\
\hline 4 & $17-29$ & Pernah/ & & \\
\hline & Total & & 95 & $100 \%$ \\
\hline
\end{tabular}


Berdasarkan tabel diatas dapat diketahui dari 95 siswa yang diteliti, sebanyak 4 siswa (4,2\%) dinyatakan memiliki Teman Sebaya yang sangat baik, 45 siswa $(47,4 \%)$ dinyatakan memiliki Teman Sebaya yang baik, 46 siswa $(48,4 \%)$ dinyatakan memiliki Teman Sebaya yang cukup dan tidak terdapat siswa yang memiliki Teman Sebaya yang buruk.

\section{Efisiensi dalam Berkonsumsi}

Panjang kelas interval diukur dari nilai skor tertinggi dikurangi nilai skor terendah kemudian dibagi banyaknya kelas interval. Banyaknya kelas interval ditentukan rentang skor, yaitu 4 sehingga ditentukan panjang kelas interval (72-18):4 $=13,5$ dibulatkan menjadi 13 .

Data efisiensi dalam berkonsumsi siswa yang diukur dengan angket/kuesioner dapat dijabarkan kedalam tabel berikut:

\begin{tabular}{lllll}
\hline No & Interval & Kriteria & Frekuensi & Prosentase \\
\hline 1 & $58-72$ & $\begin{array}{l}\text { Selalu/ Sangat } \\
\text { Baik }\end{array}$ & 39 & $41 \%$ \\
\hline 2 & $45-57$ & Sering/ Baik & 53 & $55,9 \%$ \\
\hline 3 & $31-44$ & Jarang/ Cukup & 3 & $3,1 \%$ \\
\hline 4 & $18-30$ & $\begin{array}{l}\text { Tidak Pernah/ } \\
\text { Buruk }\end{array}$ & \\
\hline & Total & 95 & $100 \%$ \\
\hline
\end{tabular}

Berdasarkan tabel diatas dapat diketahui dari 95 siswa yang diteliti, sebanyak 34 siswa $(35,8 \%)$ dinyatakan memiliki Efisiensi Berkonsumsi yang sangat baik, 58 siswa $(61 \%)$ dinyatakan memiliki Efisiensi Berkonsumsi yang baik, 3 siswa $(3,2 \%)$ dinyatakan memiliki Efisiensi Berkonsumsi yang tidak buruk dan tidak terdapat siswa yang memiliki Efisiensi Berkonsumsi yang sangat buruk.

\section{Analisis Regresi Berganda} berikut:

Hasil uji regresi berganda dari data yang telah diperoleh adalah sebagai

Berdasarkan hasil uji regresi linier berganda pada tabel di atas maka dapat diperoleh hasil persamaan sebagai berikut:

$Y=\alpha+\beta 1 X_{1}+\beta 2 X_{2}+\beta 3 X_{3}+e$

$Y=5,615+0,121+0,498 X_{2}+0,225 X_{3}$ 
Penjelasan dari fungsi regresi linier berganda di atas adalah sebagai berikut Coefficients $^{\mathrm{a}}$

\begin{tabular}{|c|c|c|c|c|c|c|c|c|c|c|c|}
\hline \multirow[t]{2}{*}{ Model } & & \multicolumn{2}{|c|}{$\begin{array}{l}\text { Unstandardi-zed } \\
\text { Coefficients }\end{array}$} & \multirow{2}{*}{$\begin{array}{l}\text { Standardized } \\
\text { Coefficients } \\
\text { Beta }\end{array}$} & \multirow[t]{2}{*}{$\mathrm{t}$} & \multirow[t]{2}{*}{ Sig. } & \multicolumn{3}{|c|}{ Correlations } & \multicolumn{2}{|c|}{$\begin{array}{l}\text { Collinearity } \\
\text { Statistics } \\
\end{array}$} \\
\hline & & $\mathrm{B}$ & \begin{tabular}{|l} 
Std. \\
Error
\end{tabular} & & & & \begin{tabular}{|l|} 
Zero- \\
order
\end{tabular} & Partial & Part & $\begin{array}{l}\text { Tolera } \\
\text { nce }\end{array}$ & VIF \\
\hline \multirow{4}{*}{1} & (Constant) & 5.615 & 7.295 & & .770 & .443 & & & & & \\
\hline & $\begin{array}{l}\text { Hasil Belajar } \\
\text { Ekonomi (X1) }\end{array}$ & .121 & .057 & .184 & 2.137 & .035 & .150 & .219 & .177 & .926 & 1.080 \\
\hline & $\begin{array}{l}\text { Lingkungan } \\
\text { Keluarga (X2) }\end{array}$ & .498 & .092 & .477 & 5.413 & .000 & .559 & .494 & .449 & .886 & 1.129 \\
\hline & $\begin{array}{l}\text { Teman Sebaya } \\
\text { (X3) }\end{array}$ & .225 & .087 & .233 & 2.573 & .012 & .339 & .260 & .213 & .836 & 1.196 \\
\hline
\end{tabular}

a. $\alpha=5,615$

Nilai konstanta ini menunjukkan bahwa apabila tidak ada variabel Hasil Belajar Ekonom (X1), Lingkungan Keluarga (X2), Teman Sebaya (X3) maka efisiensi berkonsumsi siswa (Y) akan bernilai 5,165. Dalam arti kata, efisiensi berkonsumsi siswa akan bernilai 5,165 sebelum atau tanpa adanya variabel Hasil Belajar Ekonom (X1), Lingkungan Keluarga (X2), Teman Sebaya (X3) dimana $(\mathrm{X} 1, \mathrm{X} 2, \mathrm{X} 3=0)$

b. $\beta_{1}=0,121$

Nilai parameter atau koefisien regresi variabel Hasil Belajar Ekonomi $\boldsymbol{\beta}_{\mathbf{1}}$ sebesar 0,121 artinya bahwa setiap variabel Hasil Belajar Ekonomi meningkat, maka Efisiensi Berkonsumsi akan meningkat sebesar 0,121 atau dengan kata lain setiap peningkatan Efisiensi Berkonsumsi dibutuhkan variabel Hasil Belajar Ekonomi sebesar 0,121 dengan asumsi variabel bebas yang lain tetap $(\mathrm{X} 2, \mathrm{X} 3=0)$.

c. $\beta_{2}=0,498$

Nilai parameter atau koefisien regresi variabel Lingkungan Keluarga $\boldsymbol{\beta}_{\mathbf{2}}$ sebesar 0,520 artinya bahwa setiap variabel Lingkungan Keluarga meningkat, maka Efisiensi Berkonsumsi akan meningkat sebesar 0,498 atau dengan kata lain setiap peningkatan Efisiensi Berkonsumsi dibutuhkan variabel Lingkungan Keluarga sebesar 0,498 dengan asumsi variabel bebas yang lain tetap $(\mathrm{X} 1, \mathrm{X} 3=0)$.

d. $\beta_{3}=0,181$

Nilai parameter atau koefisien regresi variabel Teman Sebaya $\boldsymbol{\beta}_{\mathbf{3}}$ sebesar 0,225 artinya bahwa setiap variabel Teman Sebaya meningkat, maka Efisiensi Berkonsumsi akan meningkat sebesar 0,225 atau dengan kata lain setiap peningkatan Efisiensi Berkonsumsi dibutuhkan variabel Teman Sebaya sebesar 0,225 dengan asumsi variabel bebas yang lain tetap.

e. $\mathbf{e}=$ error

Error merupakan kesalahan yang terjadi pada perkiraan variabel terikat (Y) karena disebabkan masih ada faktor lain selain variabel bebas (X) yang mempengaruhi variabel terikat (Y) tetapi tidak diperhitungkan. 


\section{Uji Asumsi Klasik}

Uji Normalitas

Metode yang digunakan untuk melakukan uji normalitas adalah metode Kolmogorov-Smirnov dengan mengujikannya terhadap variabel bebas dan terikat dengan menggunakan program SPSS 21 For Windows. Pedoman untuk pengambilan dalam uji normalitas ini adalah jika signifikansi $>5 \%$ atau 0,05 maka data distribusi dinyatakan normal dan atau jika signifikansi $<5 \%$ atau 0,05 maka data distribusi dinyatakan tidak normal.

\begin{tabular}{l} 
One-Sample Kolmogorov-Smirnov Test \\
\begin{tabular}{|ll|l|}
\hline & & $\begin{array}{l}\text { Unstandardized } \\
\text { Residual }\end{array}$ \\
\hline $\mathrm{N}$ & & 95 \\
Normal Parameters & & .0000000 \\
& Mean & 5.40987397 \\
& Std. Deviation & .056 \\
Most Extreme Differences & Absolute & .056 \\
& Positive & -.053 \\
Kolmogorov-Smirnov Z & Negative & .549 \\
Asymp. Sig. (2-tailed) & & .924 \\
\hline
\end{tabular} \\
\hline
\end{tabular}

Berdasarkan tabel diatas dapat dikatahui bahwa nilai signifikansi sebesar 0,549 yang bernilai lebih besar dari pada 0,05 sehingga dapat disimpulkan bahwa uji yang dilakukan berdistribusi normal.

Selain tabel diatas, untuk mengetahui normal atau tidaknya suatu penelitian dapat dilihat melalui grafik $P-P$ Plot of regression standardized residual. Deteksi normalitas dapat diketahui melalui sebaran titik-titik pada sumbu diagonal grafik. Jika data menyebar disekitar garis diagonal dan mengikuti arah garis diagonal atau grafik histogramnya menunjukan pola distribusi normal, maka model regresi memenuhi asumsi normalitas dan sebaliknya. Dan jika menggunakan grafik Histogram Standardized Regression Residual, terlihat kurva berbentuk seperti lonceng maka dapat dikatakan bahwa nilai residual tersebut menyebar secara normal.

\begin{tabular}{|c|c|c|c|}
\hline Variabel Bebas & $\begin{array}{l}\text { Nilai } \\
\text { Tolerance }\end{array}$ & VIF & Keterangan \\
\hline $\begin{array}{l}\text { (X1) Hasil Belajar } \\
\text { Ekonomi }\end{array}$ & 0,926 & 1.080 & $\begin{array}{l}\text { Non } \\
\text { Multikolinieritas }\end{array}$ \\
\hline $\begin{array}{l}\text { (X2) Lingkungan } \\
\text { Keluarga }\end{array}$ & 0,886 & 1.129 & $\begin{array}{l}\text { Non } \\
\text { Multikolinieritas }\end{array}$ \\
\hline $\begin{array}{l}\text { (X3) } \\
\text { Sebaya }\end{array}$ & 0,836 & 1.196 & $\begin{array}{l}\text { Non } \\
\text { Multikolinieritas }\end{array}$ \\
\hline
\end{tabular}


Berdasarkan tabel diatas diketahui variabel bebas dalam penelitian ini memiliki nilai VIF $<10$ dan besarnya Tolerance $>0,1$, sehingga dapat dikatakan bahwa tidak terdapat gejala multikolinieritas antara variabel bebas dalam penelitian ini.

Uji Heteroskedatisitas

\section{Scatterplot}

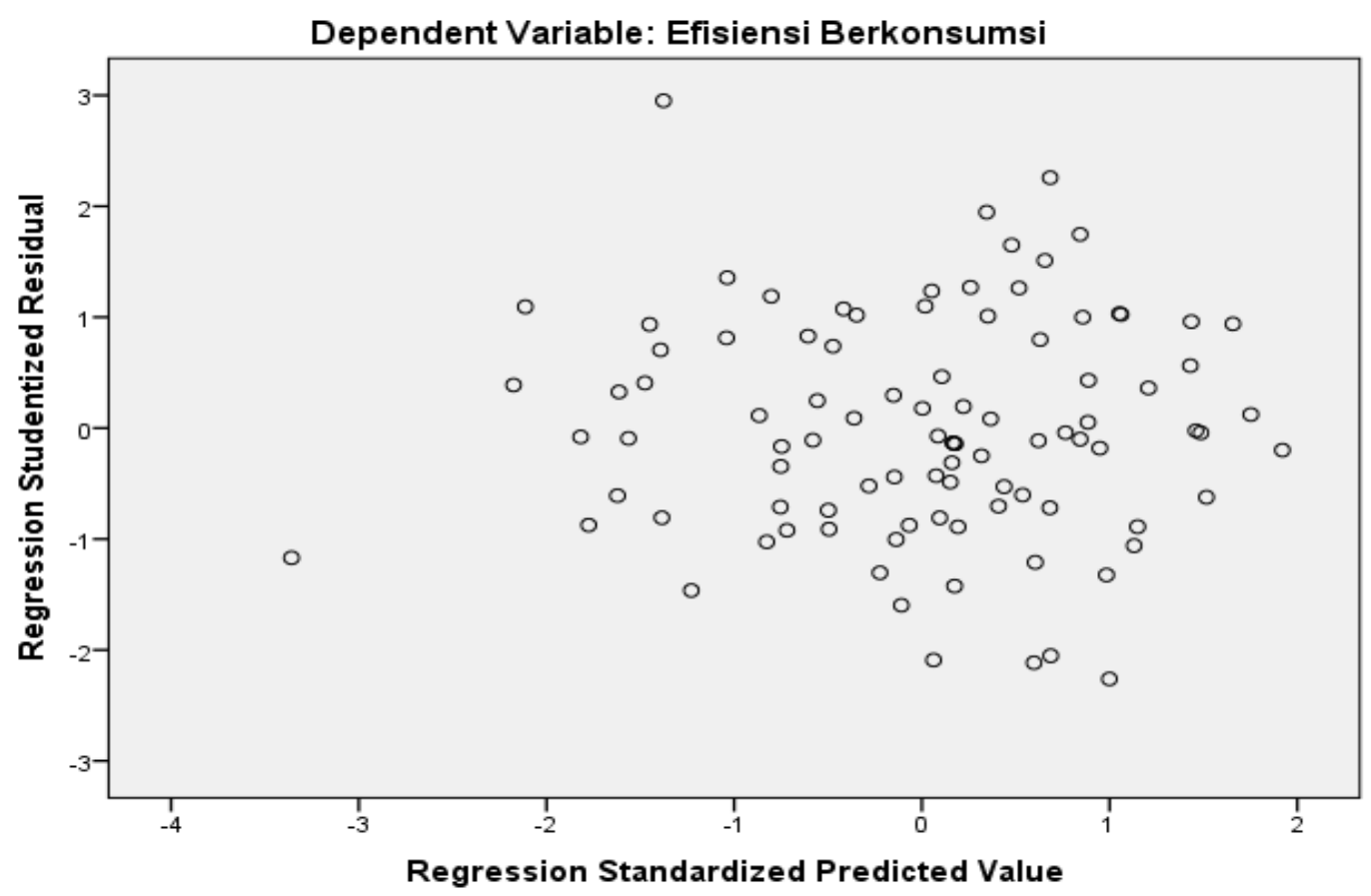

Berdasarkan grafik scatterplot pada kedua model regresi terlihat bahwa titiktitik menyebar secara acak serta tersebar di atas maupun di bawah angka nol pada sumbu Y. Dengan demikian dapat disimpulkan bahwa tidak terjadi heterokesdatisitas pada model regresi.

\section{Pengujian Hipotesis}

Uji t

\begin{tabular}{llll}
\hline Variabel Bebas & T Hitung & T Tabel & Signifikansi \\
\hline Hasil Belajar Ekonomi (X1) & 2,137 & 1,662 & 0,035 \\
& & & \\
Lingkungan Keluarga(X2) & 5,413 & 1,662 & 0,000 \\
& & & \\
Teman Sebaya(X3) & 2,573 & 1,662 & 0,012 \\
\hline
\end{tabular}


Dari tabel diatas maka dapat ditarik kesimpulkan sebagai berikut:

1. Uji t mengenai Hasil Belajar Ekonomi (X1) terhadap Efisiensi Berkonsumsi (Y) diperoleh t-hitung $(2,137)$ yang lebih besar dari t-tabel $(1,662)$ atau nilai signifikansi $(0,035)$ yang lebih kecil dari $(0,05)$ maka Ho ditolak dan Ha tidak ditolak. Hasil ini memperlihatkan bahwa variabel Hasil Belajar Ekonomi secara parsial berpengaruh signifikan terhadap Efisiensi Berkonsumsi.

2. Hasil uji mengenai pengaruh Lingkungan Keluarga(X2) terhadap Efisiensi Berkonsumsi(Y) diperoleh t-hitung $(5,413)$ yang lebih besar dari t-tabel $(1,662)$ atau nilai signifikansi $(0,000)$ yang labih kecil dari $(0,05)$ maka Ho ditolak dan Ha tidak ditolak. Hasil ini memperlihatkan bahwa variabel Lingkungan Keluarga secara parsial berpengaruh signifikan terhadap Efisiensi Berkonsumsi.

3. Hasil uji mengenai pengaruh Teman Sebaya(X3) terhadap Efisiensi Berkonsumsi(Y) diperoleh t-hitung $(2,573)$ yang lebih besar dari t-tabel $(1,662)$ atau nilai signifikansi $(0,012)$ yang lebih kecil dari $(0,05)$ maka Ho ditolak dan Ha tidak ditolak. Hasil ini memperlihatkan bahwa variabel Teman Sebaya secara parsial berpengaruh signifikan terhadap Efisiensi Berkonsumsi.

\section{Besarnya Sumbangan Efektif Masing-Masing Variabel}

a. Besarnya pengaruh variabel $\mathrm{X} 1$ terhadap variabel $\mathrm{Y}$ adalah sebesar 2,76\% dan bernilai positif.

b. Besarnya pengaruh variabel $\mathrm{X} 2$ terhadap variabel $\mathrm{Y}$ adalah adalah sebesar $26,6643 \%$.

c. Besarnya pengaruh veriabel X3 terhadap variabel Y adalah sebesar 7,8987\%.

Dari hasil perhitungan di atas dapat kita ketahui bahwa sumbangan pengaruh terbesar dari variabel independen terhadap variabel dependen adalah dari variabel X2 yaitu sebesar $24,9873 \%$.

Uji F

Dari hasil uji Anova atau uji $\mathrm{F}$ dibawah didapatkan $\mathrm{F}_{\text {hitung }}$ 18,092 dengan nilai signifikansi 0,000 . Karena $F_{\text {hitung }}>$ dari $F_{\text {tabel }}(18,092>2,70)$ dan nilai signifikansi lebih kecil dari $0,05(0,000<0,05)$ yang berarti Ho ditolak dan Ha tidak ditolak. Sehingga dapat disimpulkan bahwa variabel X1,2 dan 3 berpengaruh terhadap Y

\begin{tabular}{|c|c|c|c|c|c|}
\hline Model & \begin{tabular}{|ll} 
Sum & of \\
Squares
\end{tabular} & $d f$ & Mean Square & $\mathrm{F}$ & Sig. \\
\hline $\begin{array}{l}\text { Regression } \\
\text { Residual } \\
\text { Total }\end{array}$ & $\begin{array}{l}1640.885 \\
2751.073 \\
4391.958\end{array}$ & $\begin{array}{l}3 \\
91 \\
94\end{array}$ & $\begin{array}{l}546.962 \\
30.232\end{array}$ & 18.092 & $.000^{\mathrm{b}}$ \\
\hline
\end{tabular}




\section{Model Summary ${ }^{b}$}

\begin{tabular}{|c|c|c|c|c|c|c|c|c|c|c|}
\hline \multirow{2}{*}{$\begin{array}{l}\text { Mode } \\
\text { I }\end{array}$} & \multirow[t]{2}{*}{$R$} & \multirow{2}{*}{$\begin{array}{l}\text { R } \\
\text { Square }\end{array}$} & \multirow{2}{*}{$\begin{array}{l}\text { Adjusted } \\
\mathrm{R} \\
\text { Square }\end{array}$} & \multirow{2}{*}{$\begin{array}{l}\text { Std. Error } \\
\text { of the } \\
\text { Estimate }\end{array}$} & \multicolumn{5}{|c|}{ Change Statistics } & \multirow{2}{*}{$\begin{array}{l}\text { Durbin- } \\
\text { Watso } \\
n\end{array}$} \\
\hline & & & & & $\begin{array}{l}\text { R } \\
\text { Square } \\
\text { Change }\end{array}$ & $\begin{array}{l}\text { F } \\
\text { Chang } \\
\text { e }\end{array}$ & $\begin{array}{l}\mathrm{df} \\
1\end{array}$ & $\begin{array}{l}\mathrm{df} \\
2\end{array}$ & $\begin{array}{l}\text { Sig. F } \\
\text { Chang } \\
\mathrm{e}\end{array}$ & \\
\hline 1 & $.611^{\mathrm{a}}$ & .374 & .353 & 5.49832 & .374 & 18.092 & 3 & 91 & .000 & 2.192 \\
\hline
\end{tabular}

Koefisien Determinasi $\left(\mathrm{R}^{2}\right)$

Berdasarkan tabel di bawah dikketahui koefisien (R) yang dihasilkan sebesar 0,611 yang artinya terdapat pengaruh yang cukup kuat antara.Hasil Belajar Ekonomi (X1), Lingkungan Keluarga (X2), dan Teman Sebaya (X3) terhadap Efisiensi Berkonsumsi (Y). Koefisien determinasi $\left(\mathrm{R}^{2}\right)$ yang diperoleh sebesar 0,374 yang berarti bahwa Efisiensi Berkonsumsi dipengaruhi oleh Hasil Belajar Ekonomi, Lingkungan Keluarga dan Teman Sebaya yaitu sebesar 37,4\% sedangkan sisanya yaitu 62,6\% dipengaruhi oleh faktor lain selain Hasil Beljar Ekonomi, Lingkungan Keluarga dan Teman Sebaya atau yang tidak dikaji dalam penelitian ini.

\section{Pengaruh Hasil Belajar Ekonomi terhadap Efisiensi Berkonsumsi Siswa kelas X IPS SMA Negeri 1 Tumpang Tahun Ajaran 2015/2016.}

Dari hasil penelitian menunjukkan bahwa terdapat pengaruh antara hasil belajar ekonomi terhadap efisiensi dalam berkonsumsi. Hal tersebut dikarenakan setelah menerima pembelajaran ekonomi di sekolah, seorang siswa tentunya akan dapat lebih mengerti dan memahami hal-hal yang berkaitan dengan ekonomi, karena pada mata pelajaran ekonomi terdapat materi yang berhubungan dengan dasar-dasar ekonomi, baik itu pengertian ekonomi itu sendiri, teori perilaku produsen, teori perilaku konsumen serta prinsip-prinsip ekonomi termasuk prinsip dalam berkonsumsi. Dengan demikiian maka pembelajaran ekonomi di sekolah akan memberikan pengalaman belajar bagi seorang siswa.

Hal tersebut diatas sesuai dengan hasil penelitian Hamzah (2013) yang mengatakan bahwa "Hasil belajar Pengantar Ilmu Ekonomi pada penelitian ini memiliki pengaruh terhadap perilaku konsumsi seseorang. Dapat diasumsikan bahwa penyerapan pengetahuan yang dipelajari seseorang akan memberi bekal pada seseorang tersebut untuk berperilaku, namun dari sisi lain perilaku seseorang tidak mendasarkan pada pengetahuan yang diperolehnya bahkan jauh dari apa yang dipelajari dari disiplin ilmu yang diembannya". Dalam hal ini efisiensi berkonsumsi termasuk kedalam perilaku konsumsi yang baik. 


\section{Pengaruh lingkungan Keluarga Terhadap Efisiensi Berkonsumsi Siswa Kelas X IPS SMA Negeri 1 Tumpang Tahun Ajaran 2015/2016.}

Dari hasil penelitian menunjukkan bahwa lingkungan keluarga berpengaruh terhadap efisiensi dalam berkonsumsi seorang anak. Hal tersebut dikarenakan lingkungan keluarga merupakan lingkungan utama bagi seorang anak dan merupakan lingkungan yang paling berpengaruh terhadap tumbuh kembang seorang anak. Ihsan (2011:p.57) mengatakan bahwa "keluarga adalah merupakan lembaga pendidikan yang pertama dan utama dalam masyarakat, karena dalam keluargalah manusia dilahirkan, berkembang menjadi dewasa. Bentuk dan isi serta cara-cara pendidikan didalam keluarga akan selalu mempengaruhi tumbuh dan berkembangnya watak, budi pekerti dan kepribadian tiap-tiap manusia".

Dari berbagai aspek yang tercakup dalam pembelajaran ekonomi di lingkungan keluarga, aspek ekonomi memiliki pengaruh yang besar pada terbentuknya pola/perilaku konsumsi seorang anak.

\section{Pengaruh Teman Sebaya terhadap Efisiensi Berkonsumsi Siswa kelas X IPS SMA Negeri 1 Tumpang Tahun Ajaran 2015/2016.}

Berdasarkan hasil penelitian menunjukkan bahwa teman sebaya berpengaruh terhadap efisiensi berkonsumsi seorang siswa. Seorang siswa sekolah menengah atas banyak menghabiskan waktu mereka sehari-hari selain bersama keluarganya yaitu juga dengan teman sebayanya. Maka dari itu baik secara langsung maupun tidak teman sebaya juga turut berpartisipasi dalam pembentukan perilaku ekonomi seorang anak. Seperti yang dikatakan Suryani (2008: p.175) bahwa"teman sebaya punya peran yang cukup besar terutama bagi anak-anak remaja dalam pembentukan sikap. Adanya kecenderungan untuk mendapatkan penerimaan dari teman-teman sebayanya mendorong para anak mudah dipengaruhi oleh kelompoknya dibandingkan oleh sumber-sumber lainnya".

Dengan besarnya pengaruh teman sebaya yang dimiliki oleh seorang siswa terhadap perkembangan pola dan perilaku konsumsi mereka. Apabila seorang siswa mempunyai teman sebaya yang sebagian besar mempunyai pola konsumsi yang tidak rasional, makan bukan tidak mungkin siswa tersebut akan menganut kebiasaan yang dilakukan oleh teman-teman sebayanya. Lain halnya jika siswa tersebut mempunyai kelompok teman sebaya yang mayoritas berpandangan bahwa pola konsumsi yang tidak rasional akan merugikan bagi diri sendiri, sehingga dalam hal berkonsumsi mereka akan lebih menghargai uang yang mereka miliki untuk mereka gunakan dalam berkonsumsi dan memenuhi kebutuhannya secara efisien. 
Pengaruh Hasil Belajar Ekonomi, Lingkungan Keluarga dan Teman Sebaya terhadap Efisiensi Berkonsumsi Siswa kelas X IPS SMA Negeri 1 Tumpang.

Berdasarkan hasil uji hipotesis yang telah dilakukan pada bab IV diketahui bahwa hasil belajar ekonomi, lingkungan keluarga dan teman sebaya secara simultan atau bersama-sama berpengaruh signifikan terhadap efisiensi berkonsumsi siswa sebesar $37,4 \%$.

\section{KESIMPULAN}

Berdasarkan hasil dan pembahasan penelitian, dapat disimpilkan bahwa: 1) Ada pengaruh positif antara hasil belajar ekonomi terhadap efisiensi berkonsumsi siswa kelas X IPS SMA Negeri 1 Tumpang; 2) Ada pengaruh positif antara lingkungan keluarga terhadap efisiensi berkonsumsi siswa kelas X IPS SMA Negeri 1 Tumpang; 3) Ada pengaruh positif antara teman sebaya terhadap efisiensi berkonsumsi siswa kelas X IPS SMA Negeri 1 Tumpang; 3) Ada pengaruh positif antara hasil belajar ekonomi, lingkunan keluarga, dan teman sebaya terhadap efisiensi berkonsumsi siswa kelas X IPS SMA Negeri 1 Tumpang.

Saran yang dapat diberikan melalui penelitian ini antara lain: 1) Bagi Siswa kelas X IPS SMA Negeri 1 Tumpang: Siswa diharapkan agar dapat mengaplikasikan ilmu ekonomi yang diperoleh baik dari sekolah, keluarga, maupun masyarakat kedalam kehidupan sehari-hari, termasuk dalam hal berkonsumsi. Selain itu seorang siswa dalam berkonsumsi juga harus memperhatikan skala prioritas dan juga rasionalitas konsumsi agar dapat memenuhi kebutuhan secara maksimal; 2) Bagi Keluarga: Lingkungan keluarga hendaknya selalu menanamkan pembelajaran ekonomi yang baik terhadap anak. Hal tersebut dapat dilakukan dengan cara memberikan pengalaman dan teladan perilaku ekonomi yang baik dalam kehidupan sehari-hari khususnya dalam hal berkonsumsi agar anak dapat mengerti, sehingga dia dapat menjadi pelaku ekonomi yang baik dan efisien; 3) Bagi Peneliti Lain: Dari penelitian yang telah peneliti lakukan ini, diharapkan dilakukan penelitian lebih lanjut guna memperjelas mengenai pengaruh hasil belajar ekonomi, lingkungan keluarga dan teman sebaya terhadap efisiensi berkonsumsi dari aspek-aspek yang belum diteliti. 


\section{DAFTAR RUJUKAN}

Handoko, T. Hani (2011) Manajemen. Yogyakarta: BPFE-Yogyakarta. Ihsan, Fuad (2011) Dasar-dasar Kependidikan. Jakarta: Rineka Cipta.

Mangkunegara, A. A. Anwar Prabu (1988) Perilaku Konsumen. Bandung: PT Eresco. Rosyidi, Suherman (2004) Pengantar Teori Ekonomi (Pendekatan kepada Teori Ekonomi Mikro \& Makro). Jakarta: Raja Grafindo Persada.

Slameto (2010) Belajar dan Faktor-faktor Mempengaruhinya. Jakarta : Rineka Cipta. Sugiyono (2007) Metode Penelitian Pendidikan Pendekatan Kuantitatif, Kualitatif dan $R \& D$. Bandung: ALFABETA

Suryani, Tatik (2008) Perilaku Konsumen : Implikasi pada Strategi Pemasaran. Edisi 1. Yogyakarta: Graha Ilmu.

Tirtaraharja, Umar dan La Sulo (2005) Pengantar Pendidikan. Jakarta: Rineka Cipta bekerja sama dengan DEPDIKBUD.

Wahyono, Hari (2001) Pengaruh Perilaku Ekonomi Kepala Keluarga terhadap Intensitas Pendidikan Ekonomi di Lingkungan Keluarga. Disertasi Program Pasca Sarjana. Tidak Diterbitkan. Malang: Universitas Negeri Malang.

Hamzah, Nuraini Asriati, \& Sri Buwono (2013) Pengaruh Hasil Belajar Pengantar Ilmu Ekonomi Terhadap Perilaku Konsumsi Mahasiswa Pendidikan Ekonomi Fkip Untan Jurnal Pendidikan dan Pembelajaran (JIPP), 2 (9), 